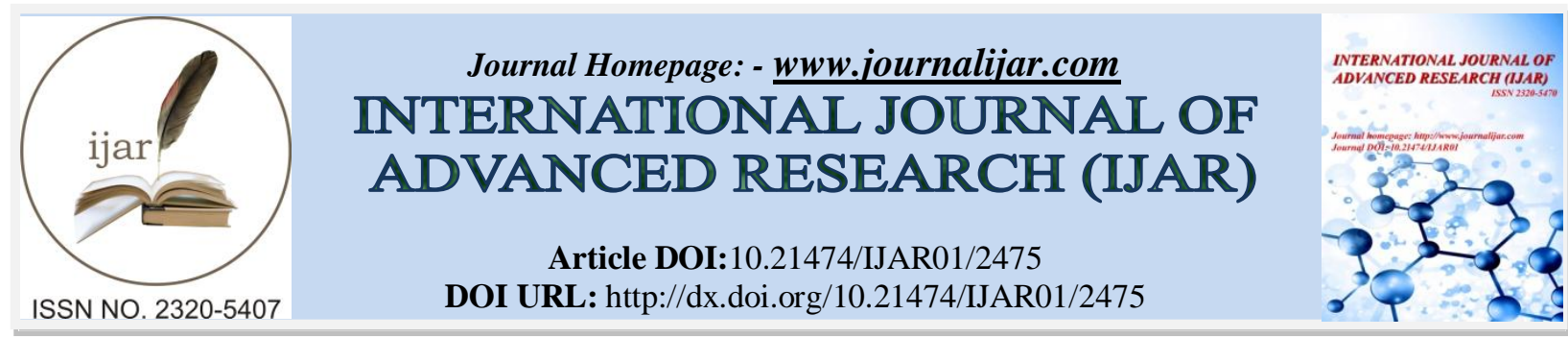

RESEARCH ARTICLE

\title{
WOMEN EDUCATION AND ITS GOALS IN MADHYA PRADESH
}

Shail Mishra.

Assistant Professor of Education G.S.College,Jabalpur,Madhya Pradesh.

\section{Manuscript Info}

Manuscript History

Received: 23 October 2016

Final Accepted: 21 November 2016

Published: December 2016

\section{Abstract}

Copy Right, IJAR, 2016,. All rights reserved.

\section{Introduction:-}

Women empowerment alludes to expanding the otherworldly, political, social, instructive, sexual orientation or monetary quality of people and groups of women. Women empowerment in India is intensely reliant on a wide range of factors that incorporate topographical area (urban/rustic) instructive status societal position (standing and class) and age. Approaches on Women empowerment exist at the national, state and nearby (Panchayat) levels in numerous divisions, including wellbeing, training, monetary open doors, sexual orientation based viciousness and political interest. However there are huge hole between strategy headways and genuine practice at the group level.

Women empowerment is basically the procedure of upliftment of financial, social and political status of ladies, the generally underprivileged ones, in the general public. It is the way toward guarding them against all types of brutality. Women empowerment includes the working up of a general public, a political situation, wherein women can inhale without the dread of abuse, misuse, worry, segregation and the general sentiment oppression which runs with being a lady in a customarily male ruled structure.

Women constitute just about half of the total populace yet India has indicated unbalanced sex proportion whereby female's populace has been relatively lower than guys. To the extent their societal position is concerned, they are not regarded as equivalent to men in every one of the spots. In the Western social orders, the ladies have measure up to right and status with men in all kinds of different backgrounds. However, gender disabilities and discriminations are found in India even today. The dumbfounding circumstance has with the end goal that she was in some cases worried as Goddess and at different times only as slave.

\section{Status of women Empowerment:-}

The status of Women Empowerment can't be pictured with single measurement rather multidimensional appraisal regarding different segments of women' life and their status would bring a reasonable origination. In this way, this paper tries to give a fundamental thought regarding the condition and status of women in wording of empowerment, education, and economic development.

\section{Hindrances of Women Empowerment:-}

Corresponding Author:- Shail Mishra.

Address:- Assistant Professor of Education G.S.College,Jabalpur, Madhya Pradesh. 
The main Problems that were faced by women in past days and still today up to some extent:

1. Gender discrimination

2. Lack of Education

3. Female Infanticide

4. Financial Constraints

5. Family Responsibility

6. Low Mobility

7. Low ability to bear Risk

8. Low need for achievement

9. Absence of ambition for the achievement

10. Social status

11. Dowry Marriage in same caste and child marriage (still existing)

12. Atrocities on Women (Raped, Kicked, Killed, Subdued, humiliated almost daily.)

Many facilities are being given to the women to make them self independend by the M.P. State Govt. Girls should go to school. Educate themselves, stands on their own feet (financially). They should have the equal participations in society and for which many plans are being operated.

\section{LadliLaxmiYojna:-}

This policy has been implemented with effect from 2007 to improve the Gender ratio Rs.6000/- per year for five year continuously total Rs.30,000 to eligible girls. The target to give benefit 30,000 such girls from this policy was made for the year 2007-08, against which 40,854 girls availed this benefit.

\section{JananiSurakshaYojna:-}

This scheme is for maternity security and to control the death rate of newly born child (infants).

\section{KanyadanYojna:-}

The chief Minister of M.P. launched this scheme for the girls from poor families. 30,000 girls got married with the efforts of the Government and the Society. Rs.5000/- is given by the Government. at the time of marriage to the girl.

\section{Education Policies:-}

"GoankiBeti" policy was introduced to motivate the girls who stand first in class. "MangalDiwas" is organized to make this plan more fruitful and successful.

\section{BetiBachaoAbhiyan:-}

BetiBachaoAbhiyan is an initiative taken by the Government of Madhya Pradesh under the personal stewardship of the Chief Minister ShriShivraj Singh Chouhan. The campaign is aimed at stopping the declining sex ratio, which is a serious problem with far reaching social ramifications and at eliminating discrimination against girls in the society. It is to increase awareness among common people to save the lives of girl child by completely removing the female foeticide. People should celebrate the birth of their girl child and educate them with full responsibility as they do for their boy child. The state's girl count has come down from 932 girls per 1000 boys in 2001 to 912 a decade later. At this rate, the next census in 2021 could show number of girls below 900.

\section{BetiBachaoBetiPadhao:-}

(Save Girl Child, Educate Girl Child) Prime Minister Modilaunched this scheme on 22 January 2015 on International Day of Girl Child in Panipat, Haryana. The trend of decline in the Child Sex Ratio (CSR), defined as number of girls per 1000 of boys between 0-6 years of age, has been unabated since 1961. The decline from 945 in 1991 to 927 in 2001 and further to 918 in 2011 is alarming. The decline in the CSR is a major indicator of women disempowerment. CSR reflects both, pre-birth discrimination manifested through gender biased sex selection, and post birth discrimination against girls. Social construct discriminating against girls on the one hand, easy availability, affordability and subsequent misuse of diagnostic tools on the other hand, have been critical in increasing Sex Selective Elimination of girls leading to low Child Sex Ratio.

Since coordinated and convergent efforts are needed to ensure survival, protection and empowerment of the girl child, Government has announced "BetiBachaoBetiPadhao" initiative. This is being implemented through a national 
campaign and focused multi sectorial action in 100 selected districts low in CSR, covering all States and UTs. This is a joint initiative of Ministry of Women and Child Development, Ministry of Health and Family Welfare and Ministry of Human Resource Development.

The objectives of this initiative are:

- Prevention of gender biased sex selective elimination.

- Ensuring survival \& protection of the girl child.

- Ensuring education and participation of the girl child.

\section{SukanyaSamridhiYojana:-}

SukanyaSamriddhiYojana was launched by the Prime Minister Mr. NarendraModi on 21st January 2015; under the BetiBachao, BetiPadhao Campaign. This scheme was launched to meet the expense of the Girl child's higher education and marriage. This scheme provides financial coverage to parents of girl children. However, the scheme would have greater impact if it were not restricted to just 2 just children.

\section{Who is eligible under this scheme?}

- Gender: Girl child only

- Citizenship: Child should be Indian citizen. NRI, OCI and other cannot open a2ccount under this scheme.

- Age limit: On the date of opening the account, the child's age should 10 years or younger.1

\section{Who can Invest:-}

Parent, or Legal Guardian of the eligible Girl child.

\section{Investment limit:-}

- In 1 year, minimum Rs 1000/- needs to be invested., thereafter in multiples of 100/-

- Maximum of Rs 1, 50,000/- can be invested.

- Deposits can be made in lump-sum or spread out manner.

- No limit on number of deposits either in a month or in a financial year.

It is necessary to bring a change in mentality in addition to Govt. polices and efforts and then only we will be able to stand with the developed countries in future to achieve the targets set for the Millennium. At the point when women push ahead the family moves, the town moves and the country moves". It is basic as their idea and their esteem frameworks lead the advancement of a decent family, great society and at last a decent country. The most ideal method for empowering is maybe through drafting women in the standard of advancement. Women empowerment will be genuine and successful just when they are enriched pay and property with the goal that they may remain on their feet and develop their personality in the general public. The Empowerment of Women has gotten to be a standout amongst the most essential worries of 21 st century at national level as well as at the global level. Government activities alone would not be adequate to accomplish this objective. Society must step up with regards to make an atmosphere in which there is no sexual orientation segregation and women have full chances of selfbasic leadership and taking an interest in social, political and monetary existence of the nation with a feeling of equity.

\section{References:-}

1. AvasthiA.P.Development Administration - Laxmi Narayan Prakashan Agra.

2. Madhya Pradesh Sandesh, March \& June 2008

3. NeetiMarg - M.I.H. Triveni Complex Roshanpura Bhopal

4. Manorama Year Book .Malayala.MaharamaPrakarh.Kotattayam

5. DainikBhaskar News Paper Dated 30 April 2008 